\title{
Dinamika Perencanaan Karir Remaja Perempuan Bali
}

\author{
Ni Made Dyah Sathya Pradnyadari dan Yohanes Kartika Herdiyanto \\ Program Studi Psikologi, Fakultas Kedokteran, Universitas Udayana \\ Dyahsathya7878@gmail.com
}

\begin{abstract}
Abstrak
Remaja memiliki tugas perkembangan diantaranya adalah melakukan perencanaan karir dan berperan dalam lingkungan sosial. Masyarakat Bali yang beragama Hindu memiliki adat istiadat dan budaya yang kental yang disosialisasikan kepada perempuan Bali sehingga perempuan Bali memiliki tanggung jawab adat yang semakin ditekankan ketika remaja. Meskipun remaja perempuan Bali berhak untuk mengembangkan karir tetapi remaja perempuan Bali tidak dapat meninggalkan budayanya, sementara remaja perempuan Bali yang sangat mementingkan budaya juga tidak dapat meninggalkan dorongan dari dalam diri untuk berkarir sehingga penelitian ini bertujuan untuk mengetahui dinamika perencanaan karir remaja perempuan Bali. Penelitian ini menggunakan metode kualitatif dengan pendekatan fenomenologi. Teknik sampling yang digunakan adalah dengan teknik purposive sampling. Responden dalam penelitian ini terdiri dari 10 orang dengan kriteria remaja perempuan berusia 18-21 tahun, bersuku Bali, sejak lahir tinggal di Bali, beragama Hindu, berstatus sebagai mahasiswa dan telah mengisi angket online pada studi pendahuluan. Teknik pengumpulan data dilakukan dengan wawancara mendalam semi terstruktur dan analisis data yang digunakan adalah theoretical coding. Penelitian ini menghasilkan suatu model dinamika perencanaan karir remaja perempuan Bali yang bergerak pada pertimbangan karir, persiapan karir dan penetapan tujuan karir dengan internalisasi budaya Bali dalam setiap proses tersebut, serta faktor internal dan eksternal sebagai faktor evaluatif dinamika.
\end{abstract}

Kata kunci: Perencanaan Karir, Remaja Perempuan Bali, Budaya Bali

\begin{abstract}
Adolescents have developmental tasks such as doing career planning and doing role in the social environment. The Balinese people who are Hinduism have strong customs and cultures that are socialized to Balinese women so Balinese women have customary responsibilities that are increasingly emphasized when adolescents. Although Balinese adolescent girl are entitled to develop careers but they can not abandon their culture, while highly cultured Balinese adolescent girls also can not leave their inner drive for a career. From that reasons, this study aims to find out the dynamics of career planning on Balinese adolescent girls. This research used qualitative method with phenomenological approach, and the sampling technique used was purposive sampling technique. Respondents in this study consisted of 10 people with some criteria such as young girls aged 18-21 years, their tribe is Bali, have been living in Bali since birth, Hinduism, have status as a collage student and selected based on the preliminary study with an online questionnaire that have been done before. Technique of data collecting was semi-deep-structured interview and the analysis of data was theoretical coding. This research resulted in a dynamics model of the career planning of Balinese adolescent girls which is engaged in career considerations, career preparation and career goal setting with the internalization of Balinese culture in each process, as well as internal and external factors as evaluative dynamics factors..
\end{abstract}

Keywords: Career Planning, Balinese Adolescent Girll, Balinese Culture 


\section{N. M. D. S. PRADNYADARI \& Y. K. HERDIYANTO}

\section{LATAR BELAKANG}

Remaja merupakan masa transisi antara masa kanak-kanak dan masa dewasa yang disertai dengan beberapa perubahan penting dalam hidupnya seperti perubahan fisik, psikologis, mental dan sosial (Hurlock, 2001). Pembatasan mengenai usia remaja sangat berbeda antara satu tokoh dengan tokoh lainnya. Sebagian besar tokoh berpendapat bahwa usia remaja diawali sejak usia 10 tahun hingga awal belasan tahun (King (2012); Hurlock (2001); Santrock (2007); Monks, Knoers, \& Haditono (2006), sementara akhir usia remaja pada usia 18 hingga 21 tahun (King (2012); Hurlock (2001), Monks dkk, (2006)). Sementara Santrock (2007) mendefinisikan akhir usia remaja adalah 22 tahun, Monks dkk (2006) membagi masa remaja dengan pembagian 12 hingga 15 tahun merupakan masa remaja awal, usia 15 hingga 18 tahun masa pertengahan dan usia 18 hingga 21 tahun merupakan masa remaja akhir. Usia 21 tahun dianggap sebagai batas kedewasaan di Indonesia (Monks, dkk., 2006).

Hurlock (2001) lebih lanjut merumuskan terdapat beberapa tugas perkembangan yang seharusnya dapat dilakukan oleh remaja, yaitu menerima keadaan fisiknya dan menggunakan tubuhnya secara efektif, dapat mencapai peran dan keterlibatan dalam lingkungan sosialnya, mencapai hubungan interpersonal dengan orang-orang disekitarnya, mencapai kemandirian emosional dari orang tua dan orang-orang dewasa lainnya serta dapat melakukan persiapan karir yang tepat untuk masa depan kehidupannya. Mengacu pada tugas perkembangan dapat dilihat bahwa menjalani peran sosial dan persiapan karir adalah tugas perkembangan yang sangat ditekankan pada masa remaja.

Persiapan karir diawali dengan perencanaan karir. Perencanaan karir adalah suatu proses untuk memutuskan tujuan-tujuan yang akan dikejar selama periode waktu mendatang dan yang akan dilakukan agar mencapai tujuantujuan yang telah ditetapkan tersebut (Simamora, 2006). Parsons (dalam Winkel \& Hastuti, 2007) merumuskan perencanaan karir sebagai proses yang dilalui sebelum melakukan pemilihan karir. Proses ini mencakup tiga aspek utama yaitu pengetahuan dan pemahaman akan diri sendiri, pengetahuan dan pemahaman akan pekerjaan, serta penggunaan penalaran yang benar antara diri sendiri dan dunia kerja. Berdasarkan uraian tersebut dapat disimpulkan bahwa kemampuan perancanaan karir adalah kecakapan atau kesanggupan individu dalam menentukan langkah yang akan dilakukan dalam karir untuk mencapai tujuan yang telah ditetapkan sesuai dengan kemampuan dan persyaratan yang meliputi pengetahuan dan pemahaman akan diri sendiri, pengetahuan dan pemahaman akan pekerjaan, serta penggunaan penalaran yang benar antara diri sendiri dan dunia kerja.

Sebuah perencanaan karir yang dilakukan sejak dini akan membuat remaja lebih siap, sehingga nantinya dapat melaksanakan setiap tugas perkembangannya dengan tepat sampai akhirnya remaja memutuskan untuk menikah dan membangun rumah tangga dengan memiliki kesiapan baik dari segi mental dan finansial (Santrock, 2007). Adapun menurut Winkel dan Hastuti (2007) faktor-faktor yang memengaruhi perencanaan karir diantaranya adalah keadaan jasmani, masyarakat, keadaan sosial ekonomi negara atau daerah, pandangan keluarga tentang peranan dan kewajiban anak lakilaki dan perempuan, taraf sosial-ekonomi kehidupan keluarga, pergaulan dengan teman-teman sebaya, pendidikan sekolah, dan gaya hidup dan suasana keluarga, serta status perkawinan orangtua. Hal ini sejalan dengan pendapat (Tracey dalam Santrock, 2007) yang mengatakan bahwa keputusan untuk melakukan perencanaan dalam rangka mempersiapkan masa depan sangat dipengaruhi oleh pengalaman individu, sosial budaya yang memengaruhi maupun peluang yang tersedia.

Dalam melaksanakan tugas perkembangan, remaja juga dituntut untuk dapat berperan dalam lingkungan sosial (Santrock, 2007). Dari pernyataan tersebut, secara tidak langsung menjadikan remaja sudah mulai memiliki tanggung jawab terhadap dirinya yang berkaitan dengan peran dalam lingkungan sosial, salah satunya berkaitan dengan budaya. Hal ini sejalan dengan pendapat Matsumoto (2008) bahwa budaya yang kental biasanya akan lebih banyak memerlukan peran dari anggota kebudayaan tersebut yang dikenal sebagai bagian dari peran sosial. Budaya yang berbeda dapat melahirkan proses kehidupan sosial yang berbeda dan melahirkan peranan sosial yang berbeda pula bagi remaja itu sendiri (Sarwono, 2011). Seligman (2001) juga menyatakan bahwa budaya yang kental akan dapat memengaruhi seorang remaja untuk mengambil keputusan khususnya dalam menentukan pilihan karir, keputusan tersebut dapat memiliki dampak yang positif dan negatif yang sangat tergantung dari pengaturan diri dan dukungan orang-orang terdekatnya.

Masyarakat Bali memiliki berbagai macam budaya yang berkembang dengan agama Hindu yang menjiwainya. Budaya Hindu Bali membuat masyarakat Bali mempunyai tugas dan tanggung jawab yang sangat kompleks khususnya perempuan Bali, karena perempuan Bali tidak hanya memiliki peran domestik dan ekonomi tetapi juga peran bermasyarakat yaitu terlibat dalam tugas-tugas adat yang merupakan ciri khas peran kehidupan perempuan Bali. Nilai-nilai budaya Hindu Bali dan berbagai tanggung jawab sebagai perempuan Bali disosialisasikan oleh orangtua, keluarga dan masyarakat sejak kecil dan semakin ditekankan ketika memasuki masa remaja (Pradnyadari, 2016).

Filsafat Agama Hindu menjiwai ideologi budaya Bali, yang berkembang menjadi sistem nilai, norma-norma dan aturanaturan, yang disebut hukum adat dan awig-awig (aturan adat) yang bercorak patrilineal (berporos pada laki-laki), yang berfungsi sebagai kontrol sosial (Wiasti, 2006). Panetje (2004) menjelaskan bahwa perempuan Bali yang sudah menikah tinggal di keluarga suaminya. Sejak berstatus menikah, perempuan Bali secara otomatis memiliki status sebagai krama adat istri (anggota perempuan dari desa adat) di lingkungan tempat tinggalnya. Hal inilah yang kemudian membuat perempuan Bali mau tidak mau harus terlibat dalam berbagai kegiatan adat di lingkungan desanya seperti menghadiri dan mengikuti berbagai kegiatan adat dan keagamaan sebagai wakil krama adat perempuan dari keluarganya (Suyadnya, 2009).

Menurut Surpha (2002) sistem kemasyarakatan di Bali mewajibkan kepada individu yang telah berumah tangga dan bertempat tinggal dalam suatu wilayah desa adat untuk 
menjadi krama banjar. Sistem tersebut ditunjang oleh hukum adat yang berlaku di Bali yaitu bagi warga yang menurut aturan adat wajib menjadi krama banjar lalu tidak menjadi krama banjar maka kepada warga dikenakan sanksi sosial antara lain dikucilkan, tidak diajak bergaul, tidak dibantu dalam keadaan bahasa, sulit mendapat kuburan bila warga mempunyai kematian dan lain sebagainya (Surpha, 2002). Surpha (2002) juga mengatakan bahwa kewajiban yang paling menonjol dalam kehidupan krama banjar adalah melaksanakan gotong royong dan persekutuan hidup bersama, baik dalam keadaan suka maupun duka. Kewajiban ini pun diturunkan kepada perempuan Bali dan disosialisasikan sejak kecil. Lebih lanjut, Surpha (2002) menyebutkan proses sosialisasi yang nampaknya berlangsung secara non formal disebabkan antara lain oleh adanya rasa tanggung jawab moral bagi keluarga maupun komunitinya yang menyangkut hubungan sesama anggota krama banjar.

Proses sosialisasi dan pengambilan keputusan terlihat jelas berbeda di dalam keluarga, termasuk dalam sosialiasi kegiatan adat dan penanaman nilai-nilai budaya Bali. Remaja perempuan Bali yang sudah terlibat dalam kegiatan adat merupakan salah satu bentuk dari peran sosial, akan tetapi ditengah keberadaan tugas tersebut seoarang remaja perempuan Bali juga harus memikirkan kehidupannya kedepan salah satunya dengan mempersiapkan karir untuk memperoleh kehidupan yang mandiri (Pradnyadari, 2016). Hal ini dikarenakan untuk mempersiapkan remaja perempuan Bali yang ketika sudah menikah dalam hal peran reproduktif, produktif dan peran sosial.

Studi pendahuluan pada Oktober 2016 menunjukkan bahwa keterlibatan remaja perempuan Bali dalam kegiatan budaya dan adat Bali agar remaja mulai mempelajari kehidupan sosial bermasyarakat di Bali terutama dalam kaitannya dengan kewajiban setelah menikah. Seperti pada wawancara dengan seorang perempuan Bali yang juga mempunyai pekerjaan formal selain sebagai ibu rumah tangga, yang mengatakan bahwa kewajiban sebagai perempuan Bali setelah menikah memang sangat banyak, sehingga remaja perempuan hendaknya mempersiapkan diri sejak remaja (Pradnyadari, 2016).

"Bikin banten, ngayah (melakukan kerja tanpa upah), ngurus anak, ngurus keluarga, belum lagi kaya Miss nikah ke adatnya yang masih kental banget. Punya pura besar, punya sanggah (tempat persembahyangan di rumah). Lelah hayati. Kadang pengen berontak tapi gak bisa kehalang punya anak. Banyak yang bertahan karena anak. Ditanya masalah cinta. Jadi hal kesekian karena lelahnya meadat"

(A, 34 tahun W1SP-A26okt L22-25)

Kepala Bidang Neraca Wilayah dan Analisis Statistik BPS Bali Didik Nursetyohadi menuturkan ketika ada banyak upacara keagamaan yang harus diikuti, maka banyak karyawan yang memilih untuk berhenti bekerja (Kristianto, 2016). Hal ini didukung oleh penelitian yang dilakukan oleh Bintang dan Astiti (2016) yang menunjukkan bahwa terdapat hubungan antara work-life balance (keseimbangan kehidupan kerja-keluarga) dengan intensi turn over (keinginan ataupun pemikiran seseorang untuk keluar dari perusahaan atas kehendak sendiri yang nampak dari ketertarikan mencari alternatif pekerjaan lain dan dorongan keluar dari perusahaan). Dapat dikatakan remaja yang yang tidak menjalani tugas perkembangannya dengan baik dapat menghambat tugas perkembangan selanjutnya pada masa dewasa, khususnya dalam hal persiapan karir dan menjalankan peran sosial. Salah satunya menimbulkan konflik kerja-keluarga hingga individu akhirnya berhenti dari pekerjaan. Memiliki peran ganda nantinya yaitu menjadi ibu rumah tangga sekaligus perempuan berkarir bukanlah sesuatu yang mudah yang mana perempuan dituntut untuk memprioritaskan keluarga tetapi tanggung jawab kerja dan karir tak dapat diabaikan. Dewi (2016) menyebutkan bahwa banyak perempuan yang rela melepas karir agar bisa lebih fokus dan konsentrasi pada keluarga. Terdapat kecenderungan ketika individu memilih suatu pekerjaan, belum melakukan eksplorasi karir.

Menurut Greenhaus, Callanan, dan Godshalk (2000) eksplorasi karir merupakan tahap yangmana individu harus melakukan pengumpulan informasi, analisis informasi maupun isu-isu yang terkait dengan karir. Greenhaus, dkk., (2000) menyatakan bahwa eksplorasi karir terdiri dari eksplorasi diri (self exploration) dan eksplorasi lingkungan (environmental exploration). Tahap eksplorasi diri dapat berupa eksplorasi terhadap ketertarikan, kelebihan, kelemahan, bakat, nilai kerja yang dianut (tantangan dalam bekerja, kemandirian dalam bekerja, keamanan, keseimbangan hidup, finansial, kondisi kerja yang akan ditempuh, pengaruh atau kekuatan) yang sesuai dengan gaya hidup individu.

Greenhaus, dkk., (2000) juga menyebutkan bahwa eksplorasi lingkungan dapat berupa eksplorasi berdasarkan tipe pekerjaan, tipe industri, kebutuhan kemampuan yang diperlukan, alternatif pekerjaan, alternatif perusahaan, serta dampaknya pada keluarga dalam keputusan karir yang ditempuh. Setelah melakukan eksplorasi terhadap diri sendiri dan lingkungan tempat individu berada maka timbulah yang disebut dengan kesadaran dalam diri individu yakni kesadaran akan diri sendiri (self) dan kesadaran terhadap lingkungan (environment) yang memungkinkan individu menyiapkan tujuan karir dan mengembangkan strategi karir yang sesuai. Individu harus teliti dan peka dalam melakukan eksplorasi, setelah melewati tahap ini individu akan mendapatkan insight mengenai dirinya sehingga lebih menyadari pilihan pekerjaan dan apa saja yang dibutuhkan, serta memikirkan terkait hambatan dan solusi yang mungkin terjadi di lingkungan (Greenhaus, dkk., 2000).

Menurut Mollenhauer (dalam Monks, dkk., 2006) supaya masyarakat bisa berfungsi dengan baik, maka seluruh warganya perlu memikul tanggung jawab bersama dan para remaja perlu dipersiapkan untuk hal tersebut. Namun sebaliknya banyak diketemukan hambatan dan rintangan bagi remaja untuk bisa ikut berpartisipasi secara kritis dalam institusi seperti keluarga, sekolah serta kehidupan usaha. Sebagian besar remaja telah mengambil sikap konformistis sehingga lebih menyesuaikan diri dengan pola masyarakat daripada dengan cita-cita sendiri. Monks, dkk., (2006) menyebutkan dalam mendidik remaja perlu diarahkan kepada hal-hal yang baik untuk menjaga keselarasan antara individu 


\section{N. M. D. S. PRADNYADARI \& Y. K. HERDIYANTO}

dan masyarakat. Hal ini sering menimbulkan bahan konflik karena remaja mempunyai ideal dan cita-cita sendiri yang tidak ditemukan dalam masyarakat. Remaja mengalami pertentangan antara apa yang diidam-idamkan dengan kenyataan yang ada (Monks, dkk., 2006).

Berdasarkan dengan tahap perkembangan karir menurut Super (dalam Gladding, 2012) eksplorasi karir terjadi pada usia 15 tahun hingga 24 tahun yang terbagi menjadi tiga subtahapan yaitu tentatif (usia 15-17 tahun), transisi (usia 18-21 tahun) dan uji coba komitmen (22-24). Pada fase transisi remaja memiliki tugas perkembangan karir mengkristalkan jabatan yang disukai. Super (dalam Gladding, 2012) mengatakan bahwa pertimbangan realitas mendapat penekanan lebih ketika masa ini, yangmana individu mulai memasuki pasar kerja atau pelatihan profesional dan upaya untuk menerapkan konsep diri terjadi pada masa transisi ini. Realitas yang dipertimbangkan remaja tidak hanya dari diri sendiri tetapi juga faktor-faktor eksternal yaitu lingkungan sosial yang artinya pada masa ini remaja sudah memasuki tahap realistis dalam kaitannya melihat kenyataan antara diri sendiri dan lingkungan sosial. Berdasarkan teori perkembangan karir, pada fase transisi ini (remaja berada pada usia 18 hingga 21 tahun) merupakan masa remaja akhir menurut Monks, Knoers, \& Haditono (2006).

Mengacu pada jenjang pendidikan, masa remaja akhir dapat dikatakan memasuki jenjang perkuliahan atau berstatus sebagai mahasiswa. Penelitian yang dilakukan Donald, Kowalski, dan Gotkin (dalam Santrock, 2007) setelah remaja meninggalkan bangku sekolah menengah atas diketahui bahwa setengah dari sejumlah remaja tidak mempunyai sistem dan arah dalam eksplorasi karir dan perencanaan karir. Hal ini didukung oleh wawancara secara non formal pada tahun 2016 yang dilakukan kepada mahasiswa Faktultas Kedokteran Universitas Udayana (FK Unud) Program Studi Psikologi, Fisioterapi dan Pendidikan Dokter yang sedang menempuh kuliah di tahun pertama (angkatan 2015), tahun kedua (angkatan 2014) dan tahun ketiga (angkatan 2013) dan mahasiswa jurusan ekonomi yang menempuh kuliah di tahun ketiga (angkatan 2013). Hasil wawancara menunjukkan tujuh dari sepuluh orang mengaku masih bingung dalam menentukan arah karir selanjutnya. Adanya kebingungan yang dialami mahasiswa seperti dalam memilih peminatan mata kuliah, memilih pekerjaan atau melanjutkan pendidikan, hal ini disebabkan oleh peran dan tanggung jawab sebagai perempuan Bali. Hal ini menunjukkan bahwa ketika remaja memasuki jenjang perkuliahan, sosiakusasu tugas dan kewajiban adat semakin ditekankan.

Pengamatan lanjutan dilakukan kepada mahasiswa Program Studi Psikologi FK Unud yang sedang mengerjakan tugas akhir (tahun angkatan 2012) tampak mengalami kebingungan setelah lulus dari perguruan tinggi. Kebingungan yang dialami adalah ketika diminta mengambil keputusan setelah lulus S1 akan bekerja atau melanjutkan kuliah Strata 2 (S2) karena mempertimbangkan rencana usia menikah. Alasan yang dikemukakan juga berkaitan dengan budaya yang mana ketika sudah menikah dan terikat dengan kewajiban adat di rumah suami, tidak mudah dalam melanjutkan pendidikan atau menempuh jenjang karir selanjutnya (Pradnyadari, 2016). Pengambilan keputusan untuk menentukan karir, tak lepas dari tatanan norma dan nilai-nilai yang terkandung dalam kehidupan bermasyarakat. Hal ini diperkuat dengan pernyataan Seligman (2001) yang menyatakan bahwa budaya yang kental dapat memengaruhi seorang remaja untuk mengambil keputusan khususnya dalam menentukan pilihan karir, keputusan tersebut dapat memiliki dampak yang positif dan negatif yang sangat tergantung dari pengaturan diri dan dukungan orang-orang terdekatnya.

Remaja mempunyai keinginan yang sangat besar dalam mengembangkan karir, salah satunya untuk memeroleh pendidikan ke luar Bali. Akan tetapi keinginan ini tidak sepenuhnya dapat terlaksana dengan alasan-a lasan budaya. Pengamatan dilanjutkan dengan diskusi secara non formal bersama A ( 21 tahun) mahasiswa Program Studi Psikologi FK Unud tahun angkatan 2013 yang sedang menyelesaikan tugas akhir, bercerita bahwa tidak dapat melanjutkan pendidikan ke luar Bali dengan alasan budaya seperti diharuskan menjadi sentana rajeg (perempuan yang menjadi poros keluarga dan meneruskan kewajiban adat sebagai kepala keluarga). A (21 tahun) tidak mempunyai saudara laki-laki dan harus melakukan kewajiban sebagai perempuan Bali di rumah, padahal pendidikan lanjutan hanya ada di luar Bali (Pradnyadari, 2016).

Survei dengan menggunakan angket online dilakukan kepada 279 remaja perempuan Hindu Bali berusia 18-21 tahun pada 7 hingga 21 Oktober 2016 di Bali. Hasil menunjukkan bahwa ketika remaja perempuan Bali diminta untuk membayangkan mempunyai keinginan melanjutkan sekolah atau bekerja ke luar Bali tetapi tidak diizinkan karena diminta untuk ngayah (kerja tanpa upah atau melayani), mebanjar (masuk anggota organisasi "banjar"), belajar mengikuti adat sebagai persiapan dalam melaksanakan kewajiban sebagai perempuan Bali setelah menikah nantinya, apakah yang akan remaja lakukan. Mayoritas remaja memilih tidak jadi sekolah atau bekerja ke luar Bali (sebesar 55\%) dan sisanya tetap mengambil keputusan untuk sekolah atau bekerja ke luar Bali (Pradnyadari, 2016).

Mayoritas kelompok remaja yang memilih tetap ke luar Bali memiliki alasan dengan tema-tema yang lebih mengarah pada alasan internal seperti ingin mengembangkan diri, sementara pada kelompok remaja yang tetap memilih di Bali mempunyai alasan yang lebih mengarah pada alasan eksternal seperti yang berhubungan dengan budaya (Pradnyadari, 2016). Hal ini menunjukkan bahwa pada satu sisi remaja perempuan Bali tetap ingin mengembangkan karirnya sementara di sisi lain remaja perempuan Bali tetap ingin mengikuti kehendak lingkungan sosialnya dalam kaitannya dengan budaya, sehingga aktualisasi atau perwujudan dirinya akan menjadi berbeda dengan keinginan pribadinya.

Ideal perkembangan individu adalah mencapai aktualisasi diri atau perwujudan diri, kenyataannya adalah remaja masih terikat akan sejarah hidupnya, masih meniti jalan yang sudah ditentukan bagi remaja oleh pendidikan dan lingkungan sosialnya (Mollenhauer dalam Monks, dkk., 2006). Idealnya 
remaja perempuan Bali berhak untuk mengembangkan karirnya dan mengaktualisaikan dirinya, kenyataannya remaja perempuan Bali mempunyai peran sosial yang secara tidak langsung menghambat keinginan pribadi remaja. Remaja perempuan Bali berhak untuk mengaktualisasikan dirinya tetapi remaja perempuan Bali tidak dapat meninggalkan budayanya, sementara remaja perempuan Bali yang sangat mementingkan budaya juga tidak dapat meninggalkan dorongan dari dalam dirinya untuk berkarir sehingga pertanyaan utama penelitian ini adalah bagaimanakah dinamika perencanaan karir remaja perempuan Bali?

\section{METODE PENELITIAN}

\section{Tipe Penelitian}

Penelitian ini menggunakan metode kualitatif. Moleong (2004) dan Poerwandari (2001) mengungkapkan bahwa penelitian kualitatif digunakan untuk menyelidiki pengalaman kesadaran manusia dengan segala kompleksitas dalam konteksnya. Pendekatan dalam penelitian ini adalah fenomenologi yaitu pendekatan yang berfokus memahami esensi dari sebuah pengalaman mengenai fenomena tertentu sehingga pendekatan ini digunakan bagi peneliti yang ingin memahami bagaimana dunia muncul kepada orang lain (Creswell, 2009; Moleong, 2004).

\section{Responden Penelitian}

Responden dalam penelitian ini dipilih dengan teknik purposive sampling, yaitu teknik pengambilan sampel sumber data dengan pertimbangan tertentu seperti orang tersebut yang dianggap paling tahu tentang apa yang harapkan (Sugiyono, 2014). Kriteria responden dalam penelitian ini adalah remaja berjenis kelamin perempuan, berusia 18-21 tahun, bersuku Bali dan beragama Hindu, sejak lahir sampai dengan pengambilan data tinggal di Bali, belum pernah menikah, berstatus aktif sebagai mahasiswa, telah mengisi angket survei studi pendahuluan.

Survei online yang dilakukan kepada 279 remaja perempuan Bali yang berusia 18 tahun hingga 21 tahun sejak 5 hingga 17 Oktober 2016. Remaja diberikan pertanyaan berupa "Bayangkan jika saudari ingin melanjutkan sekolah/kerja ke luar Bali tetapi tidak diizinkan untuk ke luar Bali oleh keluarga karena diminta untuk ngayah, belajar mebanjar, belajar adat istiadat Bali agar terbiasa melaksanakan kewajiban sebagai perempuan Bali ketika sudah menikah. Apa yang akan saudari lakukan?". Responden dipilih dengan melihat jawaban pada angket survei online dengan memilih lima orang remaja yang memiliki intensi tetap melanjutkan pendidikan atau pekerjaan ke luar Bali dan memilih lima orang remaja dengan jawaban yang berfokus pada budaya pada remaja yang memiliki intensi tetap di Bali.

Adapun gambaran responden dalam penelitian ini digambarkan sebagai berikut (Tabel 1. Tabel Karakteristik Responden. Terlampir).

Penggambaran usia responden bertujuan untuk menegaskan bahwa remaja dalam penelitian ini berada pada usia remaja akhir. Penggambaran domisili responden dikarenakan setiap daerah memiliki awig-awig yang berbeda, sehingga tempat tinggal responden cenderung berpengaruh dalam proses sosialisasi dan kewajiban adat yang dimiliki responden. Penggambaran daerah asal ayah responden dikerenakan sistem kekerabatan di Bali adalah patrilineal sehingga penurunan kewajiban adat serta awig-awig (aturan adat) yang diikuti berdasarkan daerah asal ayah responden menjadi anggota banjar adat dan menjalankan peran bermasyarakat. Adapun penggambaran bidang studi responden bertujuan untuk melihat aspirasi karir remaja perempuan Bali yang diwakili oleh responden. Responden dalam penelitian ini ketika proses pengambilan data sedang menempuh kuliah pada bidang kesehatan, bidang ekonomi, dan bidang teknologi.

\section{Lokasi Pengumpulan Data}

Penelitian dilakukan di Provinsi Bali dengan tidak memfokuskan pada kabupatan tertentu. Pengambilan data dilakukan di Kota Denpasar karena responden berdomisili di Kota Denpasar dan Kabupaten Badung. Pengambilan data pada 10 responden dilakukan di lokasi yang berdekatan dengan tempat tinggal responden dan telah disepakati oleh responden dan peneliti.

\section{Teknik Penggalian Data}

Penggalian data dalam penelitian ini dilakukan dengan wawancara mendalam semi terstruktur, observasi yang dilakukan bersamaan dengan wawancara dan penyebaran angket pertanyaan terbuka secara online. Wawancara adalah pertemuan dua orang untuk bertukar informasi dan ide melalui tanya jawab, sehingga dapat dikonstruksikan makna dalam suatu topik tertentu (Sugiyono, 2014). Sugiyono (2014) juga menyebutkan pelaksanaan wawancara semi terstruktur lebih bebas dibandingkan wawancara terstruktur, dengan tujuan untuk menemukan permasalahan secara lebih terbuka dan pihak yang diajak wawancara diminta pendapat dan ideidenya.

Survei online adalah metode pengambilan data dengan memberikan formulir berisi pertanyaan yang disebarkan melalui internet secara online. Survei melalui internet dipilih secara substansial lebih murah dan cepat, sangat fleksibel dan memungkinan populasi besar dalam jarak yang jauh, dibandingkan dengan wawancara tatap muka atau melalui telepon (Stewart \& Cash, 2014). Survei online digunakan dalam studi pendahuluan dan disebarkan melalui internet dengan teknik purposive sampling.

\section{Teknik Analisis Data}

Penelitian ini menggunakan teknik analisis data theoritical coding yang dibagi menjadi tiga bagian yaitu open coding, axial coding dan selective coding berdasarkan Strauss dan Corbin, (2003). Open coding adalah bagian analisis yang berhubungan dengan penamaan dan pengategorian fenomena melalui pengujian data secara teliti. Selama proses ini, data dipecah ke dalam bagian-bagian yang terpisah, diuji secara cermat, dibandingkan untuk persamaan dan perbedaannya, dan pertanyaan-pertanyaan yang diajukan mengenai fenomena yang tercermin dalam data. Axial coding adalah proses mengidentifikasi salah satu dari kategori dalam open coding sebagai fenomena sentral kemudian kembali ke database untuk 
mengidentifikasi apa yang menyebabkan fenomena tersebut terjadi, apa saja strategi atau aksi yang digunakan oleh para pelaku dalam merespon fenomena tersebut, apa saja konteks spesifik dan kondisi pengganggu yang memengaruhi strategi tersebut, dan apa saja konsekuensi yang dihasilkan dari strategi tersebut. Selective coding dilakukan dengan mengambil fenomena sentral dan secara sistematis menghubungkannya dengan kategori lain, memvalidasi hubungan tersebut dengan mengisi kategori yang membutuhkan penyempurnaan dan pengembangan lebih lanjut.

\section{Kredibilitas Penelitian}

Moleong (2004) mengungkapkan tujuh cara teknik pemeriksaan kredibilitas (keabsahan data) yaitu dengan perpanjangan keikut-sertaan, ketekunan pengamatan, triangulasi, pengecekan sejawat, kecukupan referensial, kajian kasus negatif dan pengecekan anggota. Teknik pemeriksaan kredibilitas yang digunakan dalam penelitian ini adalah triangulasi (triangulasi sumber, metode, dan penyidik), pemeriksaan sejawat melalui diskusi (didiskusikan dengan tiga orang rekan sejawat peneliti), dan pengecekan anggota (pengecekan data, katagori analitis, penafsiran dan kesimpulan secara formal dan informal).

\section{Isu Etik Penelitian}

Menurut kode etik HIMPSI (2010) pada pasal 20 dan 49, setiap proses di bidang psikologi yang meliputi penelitian/pendidikan/pelatihan/asesmen/intervensi yang melibatkan manusia harus disertai dengan informed consent. Pasal 48 kode etik HIMPSI (2010) mengatur tentang partisipan penelitian, dalam ayat 1 mengatur tentang psikolog dan atau ilmuwan psikologi mengambil langkah-langkah untuk melindungi perorangan atau kelompok yang akan menjadi partisipan penelitian dari konsekuensi yang tidak menyenangkan, baik dari keikutsertaan atau penarikan diri atau pengunduran dari keikutsertaan. Adapun upaya penegakan kode etik HIMPSI dalam penelitian ini dilakukan dengan cara pembuatan informed consent secara tertulis yang berisikan ketentuan-ketentuan dalam kode etik, yang kemudian dikomunikasikan secara dua arah kepada responden sebelum dilakukan proses pengambilan data wawancara dan observasi. Kesepakatan mengenai waktu dan tempat wawancara juga didiskusikan bersama sehingga tetap menjaga kenyamanan dan kerahasiaan responden dalam penelitian ini. Peneliti menjaga seluruh kerahasiaan data baik hasil survei dengan angket online, data audio rekaman wawancara maupun transkrip wawancara dan hanya mengemukakannya untuk tujuan penelitian tanpa menyebutkan identitas responden. Peneliti dan responden membina hubungan baik selama dan setelah penelitian dilakukan sesuai dengan etika yang ditentukan.

\section{HASIL PENELITIAN}

Hasil penelitian ini terdiri dari dua bagan utama yaitu bagan dinamika perencanaan karir remaja perempuan Bali dan faktor evaluatif dinamika dalam perencanaan karir remaja perempuan Bali.

\section{Gambaran Dinamika Perencanaan Karir Remaja Perempuan Bali}

(Bagan 1. Bagan Dinamika Perencanaan Karir Remaja Bali. Terlampir) Pengambilan data kepada 10 orang responden menghasilkan gambaran perencanaan karir yang dinamis, berbeda antara seorang remaja dengan remaja lainnya. Dinamika perencanaan karir remaja perempuan Bali bergerak pada pertimbangan karir, persiapan karir dan penetapan tujuan karir dengan internalisasi budaya Bali terhadap remaja akan memberikan pengaruh di setiap proses tersebut.

Adapun gambaran mengenai dinamika perencanaan karir remaja perempuan Bali dijelaskan sebagai berikut:

Gambaran Tema 1: Internalisasi Budaya pada Remaja Perempuan Bali (Bagan 2. Terlampir)

Pada remaja dengan ikatan budaya lemah memiliki beberapa aspek diantaranya mempunyai pemikiran tidak memprioritaskan budaya, pasif dalam melakukan kegiatan adat, memiliki afeksi negatif melakukan budaya, dorongan eksternal dalam melakukan budaya dan mempunyai sedikit pengetahuan terkait budaya. Pada remaja dengan ikatan budaya kuat terdiri dari beberapa aspek diantaranya mempunyai pemikiran pentingnya budaya, aktif dalam kegiatan budaya, memiliki aspek positif melakukan budaya, mempunyai dorongan internal dalam melakukan budaya dan memiliki banyak pengetahuan terkait budaya.

Gambaran Tema 2: Pertimbangan Karir pada Perencanaan Karir Remaja Perempuan Bali (Bagan 3. Terlampir)

Pada remaja dengan ikatan budaya lemah dalam melakukan pertimbangan karir berpusat pada diri sendiri-keluarga dengan aspek diri sendiri yang mendapatkan penekanan. Adapun aspek dominan berpusat pada diri sendiri-keluarga terdiri dari mempertimbangkan minat pribadi, kemampuan diri, prospek pekerjaan, lokasi tidak terikat dan pengambilan keputusan pada diri sendiri. Pada remaja dengan ikatan budaya kuat dalam membuat pertimbangan karir cenderung dominan berpusat pada keluarga-budaya, dengan budaya yang mendapatkan penekanan. Adapun aspek dominan berpusat pada keluarga-budaya terdiri dari fleksibilitas kerja, jarak dekat dengan orangtua, lokasi di Bali, ketersediaan biaya, steretotype mengenai anak perempuan, keyakinan terhadap nilai budaya tertentu dan pengambilan keputusan pada orangtua.

Gambaran Tema 3: Persiapan Karir pada Perencanaan Karir Remaja Perempuan Bali (Bagan 4. Terlampir)

Pada remaja dengan ikatan budaya lemah dalam mempersiapkan karir cenderung mempersiapkan aspek internal diantaranya pengaturan diri dan keluarga; dominansi eksplorasi diri; dan mempersiapkan keterampilan diri. Pada remaja dengan ikatan budaya kuat cenderung mempersiapkan aspek eksternal diantaranya pengaturan diri, keluarga dan bermasyarakat; dominansi eksplorasi lingkungan dan mempersiapkan keterampilan dalam budaya.

Gambaran Tema 4: Penetapan Tujuan Karir pada Perencanaan Karir Remaja Perempuan Bali (Bagan 5. Terlampir)

Pada penetapan tujuan karir remaja perempuan Bali, remaja dengan ikatan budaya lemah cenderung bersifat fleksibel, seperti lokasi pendidikan atau bekerja bebas dan pilihan pekerjaan atau pendidikan luwes. Pada remaja dengan ikatan budaya kuat cenderung bersifat terikat pada pemilihan lokasi 
bekerja dan pilihan pekerjaan atau pendidikan. Pada remaja dengan ikatan budaya kuat penetapan tujuan karir terikat memilih lokasi yang dekat dengan orangtua dan lokasi di Bali, serta terikat dalam pilihan pekerjaan atau pendidikan berdasarkan orientasi orangtua dan memungkinkan fleksibilitas waktu.

\section{Faktor Evaluatif Dinamika dalam Perencanaan Karir Remaja Perempuan Bali}

(Bagan 6. Bagan Faktor Evaluatif Dinamika dalam Perencanaan Karir Remaja Perempuan Bali. Terlampir) Terdapat faktor evaluatif yang menyebabkan dinamika perencanaan karir pada remaja perempuan Bali yang terdiri dari faktor internal dan faktor eksternal. Adapun faktor internal tersebut diantaranya ketidakseimbangan eksplorasi diri dan lingkungan, peta karir masih tentatif, penerimaan remaja pada keputusan orangtua, nilai budaya yang dianut remaja, dan perkembangan kepribadian. Faktor eksternal penyebab dinamika perencanaan karir remaja perempuan Bali diantaranya adalah fleksibilitas awig-awig (aturan adat) tiap daerah, dukungan sosial, nilai budaya yang dianut orangtua, pola asuh orangtua, dan tempat tinggal di daerah asli atau rantauan.

\section{PEMBAHASAN}

\section{Kontribusi terhadap Teori Perkembangan Karir Kontribusi}

Penelitian ini menunjukkan bahwa budaya secara langsung maupun tidak langsung menjadi pertimbangan ketika remaja melakukan perencanaan karir. Akan tetapi teori-teori perkembangan karir yang ada belum dapat menjelaskan bentuk-bentuk pengaruhnya seperti apa, serta bagaimana dinamikanya. Penelitian ini berkontribusi dalam menunjukkan bagaimana budaya berperan dalam perencanaan karir serta menunjukkan meskipun remaja perempuan Bali terikat pada budayanya, terdapat suatu kontinum yang menunjukkan terdapat ikatan budaya yang lemah dan ikatan budaya yang kuat dengan bagian-bagiannya cenderung memberikan peran pada pertimbangan karir, persiapan karir dan penetapan tujuan karir.

Hasil penelitian ini memberikan kontribusi dalam menunjukkan bahwa terdapat faktor evaluatif yang menyebabkan dinamika perencanaan karir pada remaja perempuan Bali yang terdiri dari faktor internal (ketidakseimbangan eksplorasi diri dan lingkungan, peta karir masih tentatif, penerimaan remaja pada keputusan orangtua, nilai budaya yang dianut remaja, perkembangan kepribadian) dan faktor eksternal (fleksibilitas awig-awig tiap daerah, dukungan sosial, nilai budaya yang dianut orangtua, pola asuh orangtua, tempat tinggal di daerah asli atau rantauan), yangmana sebelumnya faktor evaluatif ini belum banyak dibahas.

$\underline{\text { Kesesuaian dengan Teori }}$

Penelitian ini menunjukkan bahwa budaya secara langsung maupun tidak langsung menjadi pertimbangan ketika remaja melakukan perencanaan karir. Hal ini sesuai dengan pernyataan Seligman (2001) dan Sarwono (2011) yang mengatakan bahwa budaya berpengaruh terhadap perencanaan karir remaja.

Ketidaksesuaian dengan Teori

Hasil penelitian ini cenderung menunjukkan faktor-faktor yang memengaruhi perencanaan karir berupa pandangan keluarga tentang peranan kewajiban anak perempuan cenderung lebih dominan, selain gaya hidup dan suasana keluarga, faktor pergaulan dengan teman sebaya, keadaan jasmani, dan pendidikan sekolah cenderung tidak menjadi pertimbangan ketika melakukan perencanaan karir. Hal ini kurang sesuai dengan pendapat Winkel dan Hastuti (2007) yang mengatakan bahwa keadaan jasmani, masyarakat, keadaan sosial ekonomi negara atau daerah, pandangan keluarga tentang peranan dan kewajiban anak laki-laki dan perempuan, taraf sosial-ekonomi kehidupan keluarga, pergaulan dengan teman-teman sebaya, pendidikan sekolah, gaya hidup dan suasana keluarga, serta status perkawinan orangtua memengaruhi perencanaan karir remaja.

Ginzberg (dalam Santrock, 2007) menyebutkan bahwa pada pertengahan masa remaja, yaitu usia 17 tahun hingga awal masa dewasa disebut tahap realistis yang mana pada tahap ini cara berpikir remaja berubah dari cara berpikir subyektif ke cara berpikir realistis dan sudah terjadi pengintegrasian kapasitas dan minat. Akan tetapi pada penelitian ini tidak semua responden menunjukkan integrasi antara kapasitas dan minat misalnya responden RA (19 tahun) dan S (20) tahun yang cenderung mempunyai prestasi akademik yang kurang dibandingkan teman-temannya dan memilih karir yang tidak semata-mata sesuai dengan minat dan kemampuannya

Greenhaus, dkk (2000) menyebutkan bahwa tahapan manajemen karir (kaitannya dengan perencanaan karir) diantaranya melakukan eksplorasi karir (career exploration), kesadaran akan diri dan lingkungan (awareness of self and environmental), menetapkan tujuan yang ingin dicapai (goal setting), sementara pada penelitian ini, hasil menunjukkan tahap yang dapat bolak-balik, yangmana justru ketika remaja melakukan pertimbangan karir remaja tidak banyak melakukan eksplorasi karir. Eksplorasi karir lebih banyak dilakukan sejalan dengan melakukan persiapan karir.

\section{Faktor Evaluatif Dinamika Perencanaan Karir Remaja Perempuan Bali}

Perencanaan karir remaja perempuan Bali menunjukkan pergerakan yang dinamis, bergerak sesuai situasi sosial yang di hadapi oleh masing-masing remaja. Setiap remaja memiliki dinamikanya masing-masing sesuai dengan perkembangan kehidupannya. Hal ini sesuai dengan yang pernyataan Monks, dkk (2006) yang mengatakan bahwa meskipun pilihan pekerjaan merupakan suatu tugas perkembangan remaja dan masa dewasa awal, namun hal itu belum menunjukkan pilihan yang dilakukan pada masa itu sudah merupakan pilihan yang mantap. Adapun faktor evaluatif penyebab dinamika dalam perencanaan karir remaja dapat dibahas sebagai berikut Penetapan tujuan karir yang masih tentatif

Penetapan tujuan karir yang masih tentatif menjadi salah satu faktor evaluatif dinamika perencanaan karir remaja perempuan Bali. Hal ini sejalan dengan pernyataan Monks dkk, (2006) yang menyebutkan bahwa pilihan pekerjaan yang sungguhsungguh bukanlah suatu pilihan yang hanya sesaat, melainkan 


\section{N. M. D. S. PRADNYADARI \& Y. K. HERDIYANTO}

hasil suatu proses pemikiran dan pengalaman tertentu, meskipun hasil proses tersebut dapat menjadi keputusan yang bersifat sementara. Pada penelitian ini remaja belum menetapan tujuan karir secara tetap, sebagian besar remaja masih mengatakan bahwa bidang karir yang dipilih ataupun pekerjaan yang akan ditekuni dapat berubah kembali.

Nilai budaya yang dianut orangtua

Dinamika yang terjadi pada remaja perempuan Bali dalam hal perencanaan karir salah satunya diakibatkan karena nilai budaya yang dianut oleh orangtua juga dianut oleh remaja. Pada orangtua dengan nilai budaya yang kuat, membuat nilai budaya dalam hal pertimbangan karir remaja juga berdasarkan budaya. Hal ini sejalan dengan pendapat Sarwono (2011) yang menyebutkan bahwa agama dan pendidikan bisa memengaruhi kelakuan individu yang mana ditimbulkan oleh norma dan nilai yang berlaku dalam keluarga yang diturunkan melalui pendidikan dan pengasuhan orangtua terhadap anak-anak secara turun menurun. Hal ini menyebabkan nilai-nilai yang dianut oleh orangtua juga dianut oleh remaja akan mempengaruhi proses perencanaan karir remaja.

$\underline{\text { Pola asuh orangtua serta penerimaan remaja pada keputusan }}$ orangtua

Pola asuh orangtua dan penerimaan remaja pada keputusan orangtua juga menjadi faktor evaluatif dinamika perencanaan karir remaja perempuan Bali. Sarwono (2011) menyatakan bahwa remaja mengalami konflik peran sosial yang mana disatu pihak remaja ingin mandiri sebagai orang dewasa sementara di lain pihak masih harus terus mengikuti kemauan orangtua. Rasa ketergantungan pada orangtua di kalangan anak-anak Indonesia lebih besar karena memang dikehendaki demikian oleh orangtua (Sarwono, 2011). Pola harapan orangtua Indonesia menurut penelitian C. Kagitcibasi diwakili oleh suku-suku Jawa dan Sunda pada tahun 1984 (dalam Sarwono, 2011) yang menekankan agar anak selalu menurut pada orangtua ada kecenderungan dalam rangka agar anak menjadi orang yang seperti dicita-citakan oleh oleh orangtua. Hal ini sejalan pula dengan pendapat Monks dkk, (2006) yang mengatakan bahwa pengaruh ayah terhadap pilihan pekerjaan pada anak wanita penting. Pengaruh ayah merupakan perpanjangan pengaruh lingkungan yang selanjutnya memberikan arah pada pemilihan pekerjaan anak. Hal inilah yang menyebabkan pola asuh orangtua dan penerimaan remaja pada keputusan orangtua mempengaruhi dalam perencanaan karir remaja.

Dukungan sosial dan perkembangan kepribadian

Dukungan sosial, perkembangan kepribadian, ketidakseimbangan eksplorasi diri dan lingkungan menjadi faktor evaluatif dinamika perencanaan karir remaja perempuan Bali. Hal ini sejalan dengan pendapat Buhler (dalam Monks dkk, 2006) yang mengatakan bahwa proses pemilihan pekerjaan sangat dipengaruhi oleh perkembangan konsep diri. Pendapat Buhler juga didukung oleh Wiegersma (dalam Monks dkk, 2006) yang mengatakan bahwa pemilihan pekerjaan yang pasti ditentukan menentukan batas kemampuan individu atas dasar potensi psikis dan fisik dan juga atas dasar pembentukan dan bantuan yang datang dari lingkungan. Faktor yang memberikan arah dan dorongan datang dari sejumlah faktor personal, sosiologis, sosialekonomis dan sifat watak individu. Oleh karena itu, dukungan sosial, perkembangan kepribadian dan ketidakseimbangan eksplorasi diri dan lingkungan menjadi penyebab dinamika perencanaan karir remaja perempuan Bali.

Fleksibilitas awig-awig

Provinsi Bali yang memiliki delapan kabupaten dan satu kotamadya memiliki adat istiadat yang berbeda pada masingmasing kecamatannya, bahkan dalam satu kecamatan adat istiadat masing-masing desa bisa berbeda sesuai dengan awigawig yang dimiliki dengan kebutuhan yang berbeda pada tiaptiap desa. Hal inilah yang menyebabkan dinamika budaya dalam kaitannya dengan sikap terhadap adat istiadat remaja perempuan Bali berhubungan dengan masyarakat. Monks dkk, (2006) mengatakan bahwa hubungan individu dengan masyarakatnya menjadi semakin penting pada masa remaja, sehingga remaja yang terhubung dengan adat istiadat yang berbeda pada masing-masing daerahnya cenderung menunjukkan suatu dinamika dalam kaitannya dengan merencanakan karir.

Useem dan Useem (dalam Sarwono 2011) menyebutkan bahwa masyarakat transisi dinamakan modernizing society yang berbeda dengan tradition oriented society (masyarakat tradisional) dan modern society (masyarakat modern). Dikatakan bahwa ciri masyarakat tradisional adalah mencoba mengekalkan nilai-nilai dari masa lalunya ke masa depan dengan cara mempraktekkan terus adat-istiadat, upacaraupacara, dan kebiasaan kebiasaan yang sudah berlaku sejak jaman nenek moyang. Masyarakat transisi adalah masyarakat yang sedang mencoba untuk membebaskan diri dari nilai-nilai masa lalu dan menggapai masa depan dengan terus menerus membuat nilai-nilai baru atau hal-hal baru. Masyarakat modern adalah masyarakat yang bertatanan luas dengan berbagai sistem nilai yang secara terbuka dinyatakan ada dan orang bebas memilih sistem nilai mana yang akan dianut. Nilai-nilai tradisional pun diakui sebagai salah-satu alternatif dan hidup berdampingan dengan nilai-nilai yang baru. Hal ini terjadi pada remaja dengan ikatan budaya kuat cenderung masih menjadi masyarakat tradisional sementara pada remaja dengan ikatan budaya lemah cenderung merupakan masyarakat modern.

Sistem sosial yang hirarkis di Bali selatan dan Timur banyak memperoleh informasi dan semangat dari sistem warna atau kasta. Masyarakat Bali Selatan nampaknya belum banyak melakukan perubahan-perubahan pada sistem sosial tentang warna (kasta), terutama di Gianyar, Klungkung, dan Bangli karena sistem warna telah mengakar di dalam seluruh bidang kehidupan tradisional. Hubungan sosial masih kelihatan sangat hierarkis dalam kehidupan sehari-hari (Sujana, 1999). Masyarakat Bali sebenarnya sangat jamak dan heterogen bukan hanya disebabkan oleh sistem sosial yang di dukung oleh sisten warna atau kasta serta sekte-sekte namun juga didukung oleh sistem kekerabatan dan keluarga yang sangat kompleks dan rumit. Otonomi banjar dan desa adat di masa lampau telah mendorong masing-masing warga dalam mengembangkan tradisi, adat, kebiasaan lokal yang berbedabeda dengan banjar dan desa adat lain terutama di Bali Barat dan Bali Timur (Sujana, 1999). Warga masyarakat kini semakin ketat dalam memakai dan mengatur waktu karena kegiatan-kegiatan manusia semakin kompleks dan banyak. "Ngayah di dalam desa adat" tidak lagi beberapa hari, tetapi 
kini cukup satu atau dua jam saja. Perempuan-perempuan tidak lagi seluruhnya gotong royong membuat sajen, namun cukup membeli saja dari sekelompok warga yang ahli tentang sajen (Sujana, 1999). Hal inilah yang menyebabkan nilai budaya yang dianut oleh orangtua menjadi berbeda dan menurun pada remaja sehingga terjadi dinamika perencanaan karir remaja perempuan Bali

Ketidakseimbangan antara eksplorasi diri dan lingkungan.

Ketidakseimbangan antara eksplorasi diri dan lingkungan membuat pertimbangan-pertimbangan karir dalam upaya penetapan tujuan karir menjadi bergerak dan tentatif. Dalam keadaan yang normal maka orang dapat memilih suatu pekerjaan yang disenanginya. Ketika lebih banyak orang yang mencari pekerjaan daripada lapangan pekerjaan yang ada maka sifat memilih juga berkurang. Bila terdapat kecenderungan sedikit saja untuk memilih, maka individu akan memilih pekerjaan yang paling dekat dengan bakat dan perhatiannya (Monks dkk, 2006).

\section{KESIMPULAN DAN SARAN}

\section{Kesimpulan}

Berdasarkan hasil penelitian dapat disimpulkan dinamika perencanaan karir remaja perempuan Bali bergerak pada pertimbangan karir, persiapan karir dan penetapan tujuan karir yangmana internalisasi budaya Bali terhadap individu akan memberikan pengaruh di setiap proses tersebut. Remaja perempuan Bali dengan ikatan budaya yang kuat melahirkan dasar pertimbangan karir yang berpusat pada rentang keluarga dan budaya dengan budaya yang ditekankan, sementara remaja perempuan Bali dengan ikatan budaya yang lemah memiliki dasar pertimbangan karir berpusat pada rentang diri sendiri dan keluarga dengan aspek diri sendiri yang ditekankan. Remaja perempuan Bali dengan ikatan budaya yang kuat cenderung dominan mempersiapkan aspek eksternal dalam perencanaan karir sementara remaja perempuan Bali yang memiliki ikatan budaya lemah dominan mempersiapkan aspek internal. Remaja perempuan Bali dengan ikatan budaya yang kuat dalam penetapan tujuan karir cenderung lebih bersifat terikat, sementara remaja dengan ikatan budaya yang lemah cenderung lebih fleksibel. Terdapat faktor evaluatif yang menyebabkan dinamika perencanaan karir pada remaja perempuan Bali yang terdiri dari faktor internal dan faktor eksternal.

\section{Saran}

Kepada remaja perempuan Bali hendaknya dapat mengidentifikasi diri apakah sudah melakukan perencanaan karir dengan bijaksana dan telah melakukan peran sosial bermasyarakat secara seimbang. Kepada orangtua yang beragama Hindu Bali yang memiliki anak perempuan dapat mengkomunikasikan mengenai konsekuensi setiap pilihan dan membantu remaja perempuan Bali dalam melakukan perencanaan karir. Kepada institusi pendidikan tinggi diharapkan dapat membantu remaja yang memasuki masa perkuliahan dengan melakukan pendampingan melalui konseling karir sehingga remaja dapat melakukan eksplorasi diri dan lingkungan. Bagi organisasi industri dan pembuat kebijakan diharapkan dapat mengembangkan programprogram sosialisasi mengenai praktik ketika bekerja melalui media magang, seminar atau semacamnya sehingga semakin mendukung remaja dalam melakukan eksplorasi karir pada bidang pekerjaan Kepada peneliti selanjutnya diharapkan dapat meneliti remaja dengan karakteristik responden dalam bidang karir yang lain, wilayah penelitian yang lebih bervariasi seperti di pedesaan, serta memperluas cakupan asal daerah remaja perempuan Bali agar penelitian mengenai perencanaan karir semakin mewakili fenomena remaja perempuan Bali.

\section{DAFTAR PUSTAKA}

Bintang, S. K., \& Astiti, D. P. (2016). Work-life balance dan intensi turnover pada pekerja wanita Bali di desa adat Sading, Mangupura, Badung. Jurnal Psikologi Udayana, 3(3), 382394.

Creswell, J. W. (2009). Research design (Pendekatan kualitatif, kuantitatif dan mixed. Yogyakarta: Pustaka Pelajar.

Dewi, C. K. (2016). Peran perempuan Hindu: Antara reproduksi dan aktualisasi diri. In Perempuan \& kesuburan (pp. 6-13). Denpasar: Pustaka Ekspresi

Gladding, S. T. (2012). Konseling: Profesi yang menyeluruh. Jakarta: PT. Indeks.

Greenhaus, J. H., Callanan, G. A., \& Godshalk, V. M. (2000). Career management. Fort Worth: Dryden Press.

HIMPSI. (2010). Kode etik psikologi Indonesia. Jakarta: Pengurus Pusat Himpunan Psikologi Indonesia.

Hurlock, E. (2001). Psikologi perkembangan. Jakarta: Erlangga.

King, L. A. (2013). Psikologi umum: Sebuah pandangan apresiatif. (B. Marwendsdy, Penerj.) 2013.

Kristianto, F. (2016, Mei 4). Pengangguran di Bali pada februari 2016 membludak, ini pemicunya. Retrieved from Bisnis.com:

http://finansial.bisnis.com/read/20160504/9/544686/pengan gguran-di-bali-pada-februari-2016-membeludak-inipemicunya

Matsumoto, D. (2008). Pengantar psikologi lintas budaya. Yogyakarta: Pustaka Belajar.

Moleong, L. J. (2004). Metodologi penelitian kualitatif. Bandung: Remaja Rosdakarya.

Monks, F. J., Knoers, A. M., \& Haditono, S. R. (2006). Psikologi perkembangan: Pengantar dalam berbagai bagainnya. Yogyakarta: Gadjah Mada University Press

Panetje, G. (2004). Aneka catatan tentang hukum adat Bali. Denpasar: CV. Kayu Mas.

Pradnyadari, N. M. (2016). Dinamika perencanaan karir remaja perempuan Bali: Sebuah studi pendahuluan (tahun 2016). Denpasar: tidak dipublikasikan.

Santrock, J. W. (2007). Remaja, edisi keduabelas. Jakarta: Penerbit Erlangga

Sarwono, S. W. (2011). Psikologi remaja. Jakarta: Rajawali Pers

Seligman, L. (2001). Development career counseling and assesment. Virginia: George Mason University.

Seligman, L. (2001). Development career counseling and assesment. Virginia: George Mason University.

Simamora, H. (2006). Manajemen sumber daya manusia. Yogyakarta: STIE YKPN.

Stewart, C. J., \& Cash, W. B. (2014). Interviu: Prinsip dan praktik. (W. W. Mahendra, Trans.) Jakarta: Salemba Humanika.

Strauss, \& Corbin. (2003). Dasar-dasar penelitian kualitatif. Yogyakarta: Daftar Pustaka.

Sugiyono. (2014). Metode penelitian pendidikan: Pendekatan kuantitatif, kualitatif dan R \& D). Bandung: Alfabeta.

Sujana, N. N. (1999). Kompleksitas dan dinamika di tengah bangunan kebudayaan Bali. In Bali dan masa depannya (pp. 37-60). Denpasar: Bali Post. 


\section{N. M. D. S. PRADNYADARI \& Y. K. HERDIYANTO}

Surpha, I. (2002). Seputar desa pakraman dan adat Bali. Denpasar: Bali Post.

Suyadnya, I. (2009). Balinese women and identities: Are they trapped in traditions, globalization or both? Journal Unair, Retrieved from Journal.unair.ac.id.

Wiasti, N. M. (2006). Hubungan industrial yang berwawasan gender: Studi kasus pada industri kerajinan bambu di Desa Belega, Kabupaten Gianyar, Bali. Jurnal Kembang Rampai Perempuan Bali, 134-153p

Winkel, \& Hastuti, S. (2007). Bimbingan dan konseling di institusi pendidikan. Yogyakarta: Media Abadi. 
LAMPIRAN

Tabel 1

Tabel Karakteristik Responden

\begin{tabular}{llllll}
\hline No & Inisial & Usia & Domisili & $\begin{array}{l}\text { Daerah asal } \\
\text { ayah }\end{array}$ & Bidang Studi \\
\hline 1 & RA & 19 & Badung & Badung & Psikologi \\
2 & GB & 20 & Badung & Badung & Kedokteran \\
3 & S & 20 & Denpasar & Tabanan & Psikologi \\
4 & GI & 19 & Denpasar & Tabanan & Kedokteran \\
5 & T & 21 & Denpasar & Denpasar & Sistem Informasi \\
6 & GM & 18 & Badung & Badung & Farmasi \\
7 & A & 19 & Badung & Tabanan & Manajemen \\
8 & Y & 19 & Badung & Buleleng & Manajemen \\
9 & CH & 21 & Denpasar & Jembrana & Fisioterapi \\
10 & DP & 19 & Denpasar & Bangli & Psikologi \\
\hline
\end{tabular}




\section{Bagan 1}

Bagan Dinamika Perencanaan Karir Remaja Perempuan di Bali

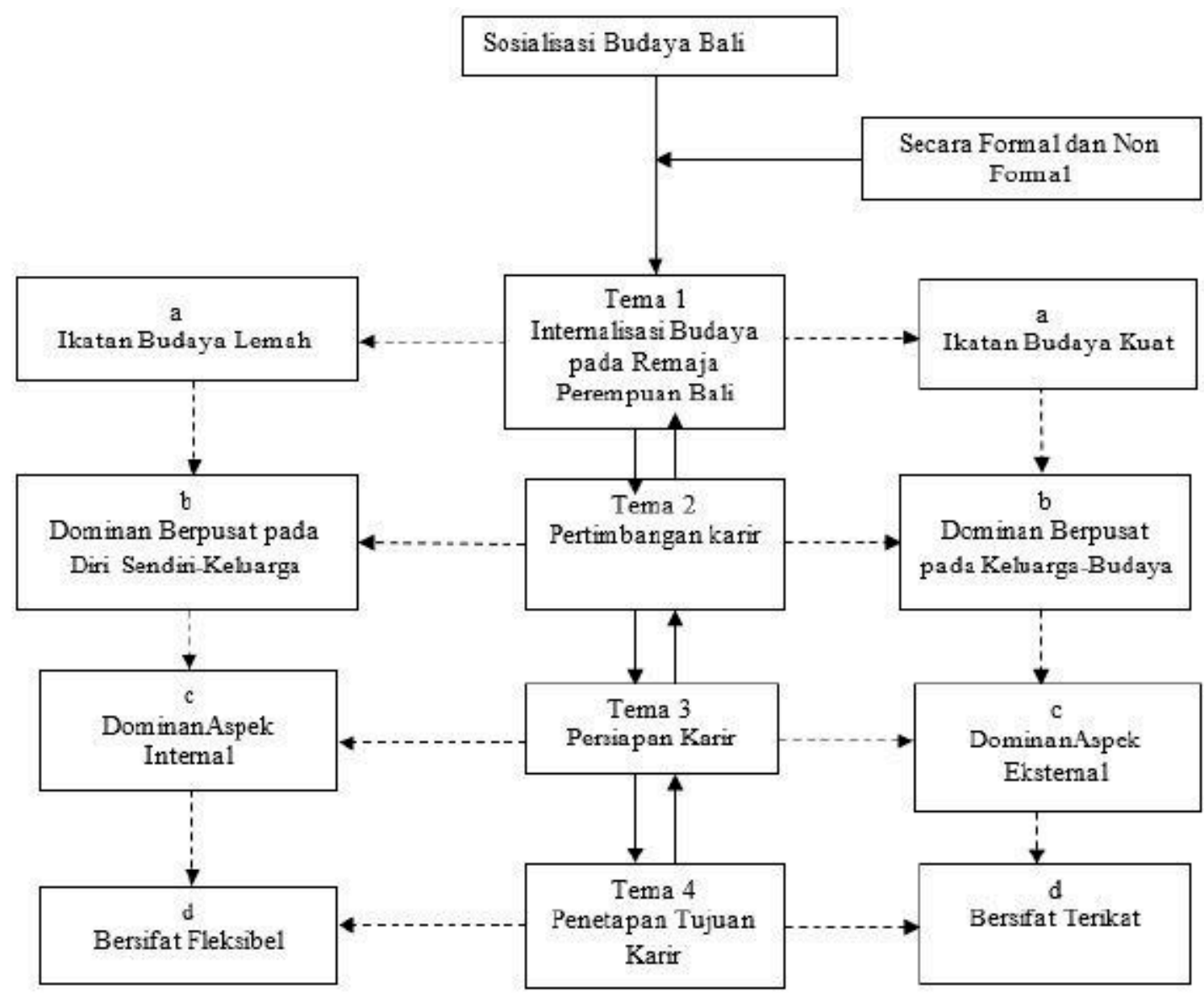

Keterangan:

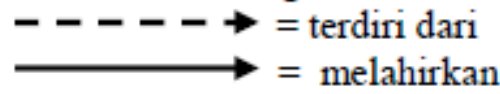




\section{Bagan 2}

Gambaran Tema 1 Internalisasi Budaya pada Remaja Perempuan Bali

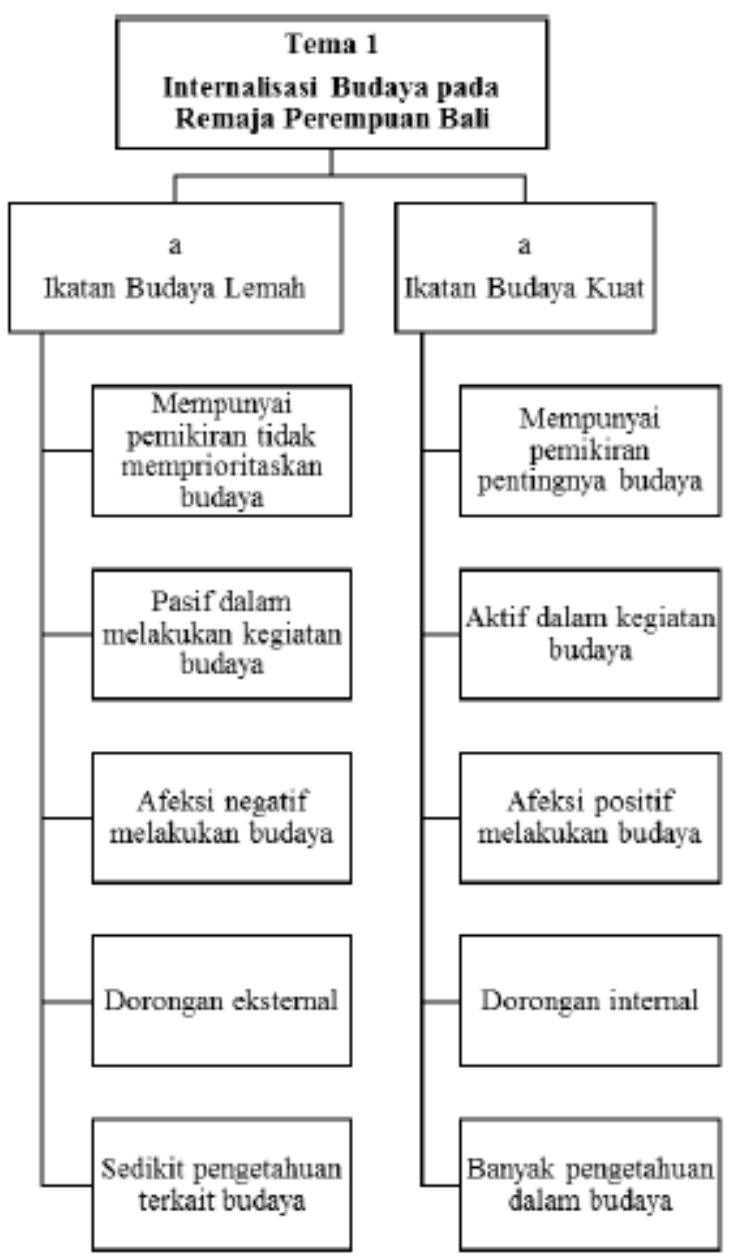




\section{N. M. D. S. PRADNYADARI \& Y. K. HERDIYANTO}

\section{Bagan 3}

Gambaran Tema 2 Pertimbangan Karir Dominan pada Perencanaan Karir Remaja Perempuan Bali

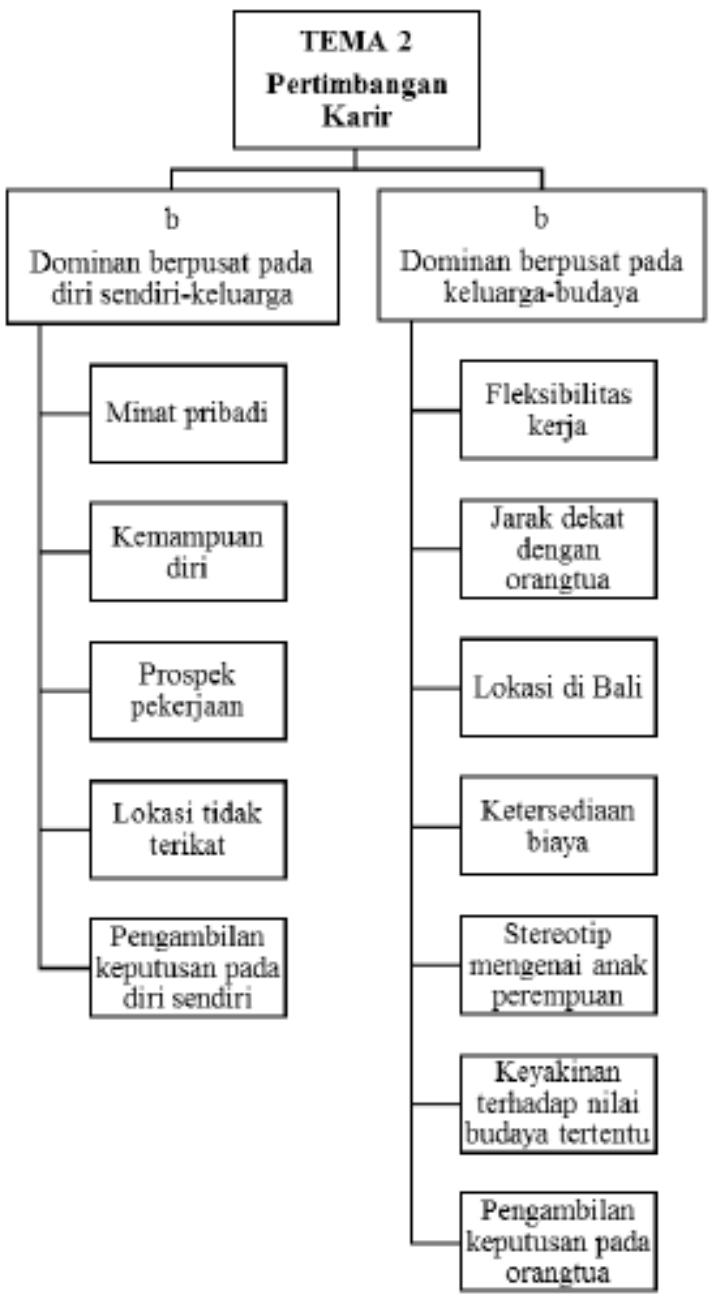




\section{Bagan 4}

Gambar Tema 3 Persiapan Karir Dominan pada Perencanaan Karir Remaja Perempuan Bali

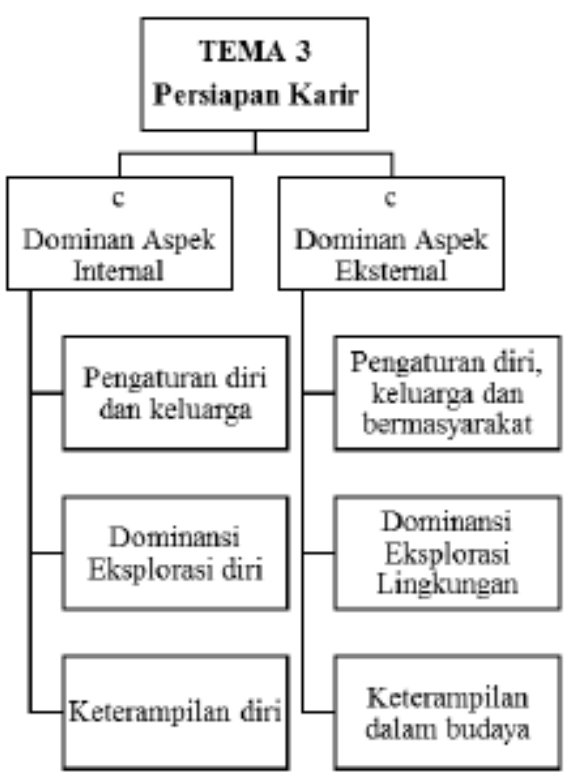




\section{Bagan 5}

Gambar Tema 4 Penetapan Tujuan Karir pada Perencanaan Karir Remaja Perempuan Bali

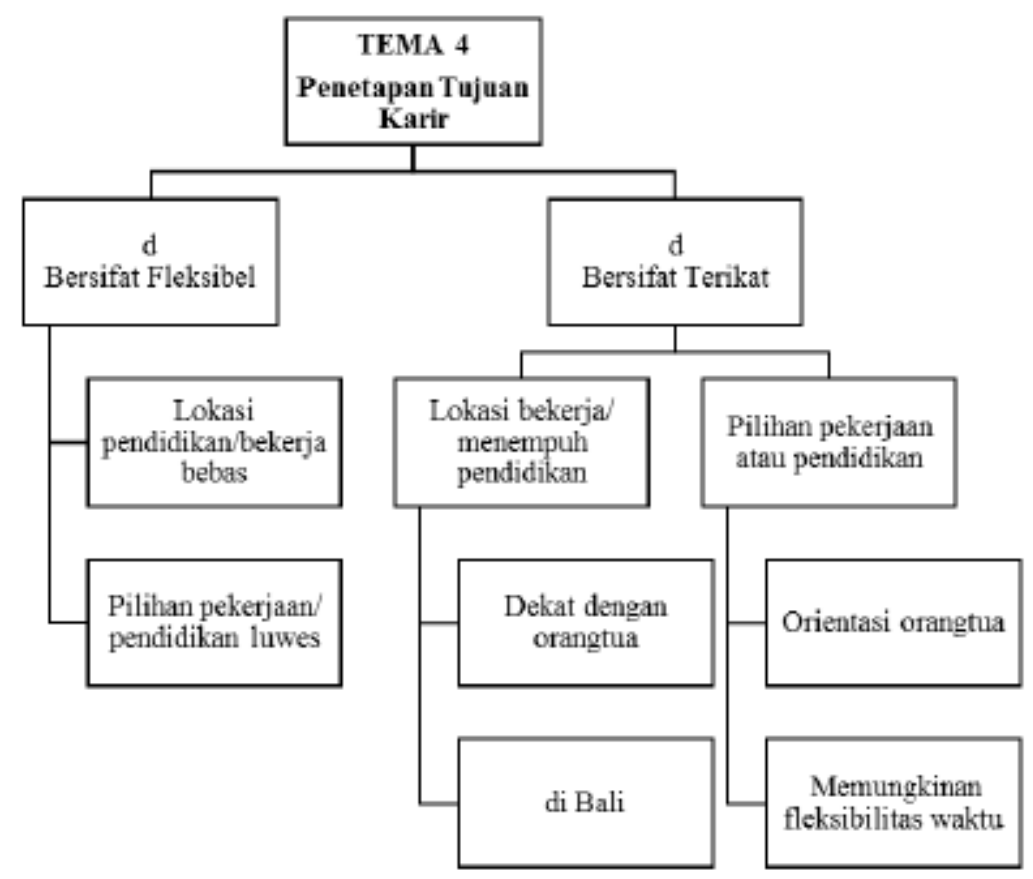




\section{Bagan 6}

Bagan Faktor Evaluatif Dinamika dalam Perencanaan Karir Perempuan Bali

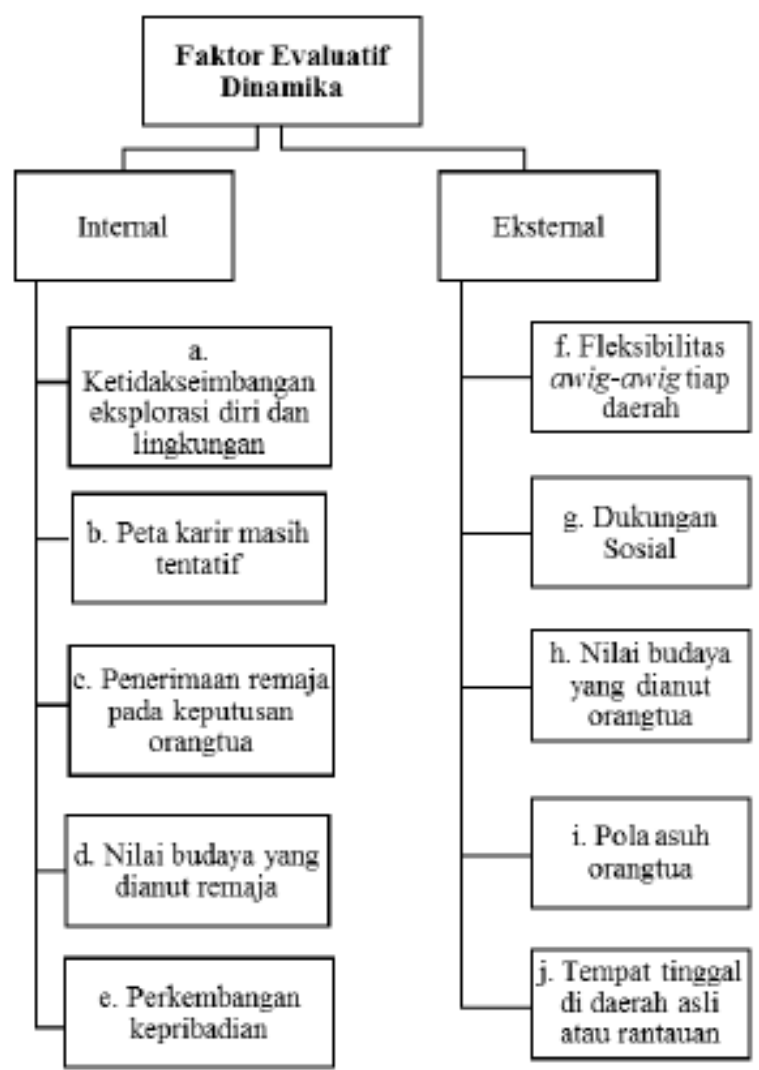

